\title{
Evaluation of a storm flow management design to contain runoff within the watershed using ponds in series
}

\author{
H. Ahmad ${ }^{1} \&$ J. W. Miller ${ }^{2}$ \\ ${ }^{I}$ Civil and Environmental Engineering Program, \\ Florida State University, USA \\ ${ }^{2}$ George and Associates Consulting Engineers, Inc., USA
}

\begin{abstract}
In a closed basin, where runoff is not allowed to discharge outside the watershed, a systematic design of storm water routing with retention facility is necessary to manage the runoff. This article presents a successful design to route the excess runoff generated due to the change in land-cover from an 11.4 acre site in Tallahassee, Florida, USA. The site development involved conversion of a wooded area to an aquatics complex with pools, buildings, parking lots, and driveway access etc. creating 2.4 acre impervious area. A pond with adequate storage capacity was not feasible to construct within the site due to site constraints and high-cost. The runoff generated from the new impervious area was designed to route through the newly designed small onsite dry-detention pond and discharged to an existing offsite pond, located within a closed basin. The analysis showed successful design of an onsite pond that retains as much water as possible within the site and safely releasing excess volume downstream to the offsite pond. The results confirmed that the offsite pond in the closed basin can retain all runoff without any discharge and the two ponds in series can handle any extreme storm in an integrated manner.
\end{abstract}

Keywords: site development, runoff, routing, pond, closed basin, ICPR.

\section{Introduction}

The process of urbanization increases impervious area, which in turn results in increased runoff. In addition, the changes in slope of land surface, reduced 
infiltration, and increased velocity of overland flow generate greater volume of runoff, discharging in shorter time [1-3] causing floods. With the increasing complex nature of urbanized watershed, storm water management has become a challenge in recent years. An effective engineering design with appropriate analysis (analytical model development) is a requirement for any complex urban storm water mitigation.

The alteration of land cover requires the assessment of the effects (e.g. change in runoff rate, runoff volume) of development, so that preventive management can be adopted [4]. Therefore, urban storm water management models are widely recognized as useful tools for urban planning and design to avoid any adverse impact at the downstream of the project area [5]. Many state or regulatory agencies require the design to attenuate the post-development peak flow to predevelopment level for one or more design storms with a given return period and storm duration [6]. The guideline for closed basin is even stricter and requires the basin to retain all runoff. The ultimate destination of the runoff in most land development project is usually a surface stream or a reservoir. However, the design becomes complex if the increased runoff from the site must be contained within the watershed with a finite volume pond system.

This article presents a design and analysis of storm water management associated with the development of an 11.4 acre site. Since a large storage facility within the project area was not feasible, the design considered providing a small detention pond within the site and using an offsite pond (located in a closed basin) to support the onsite pond. The design was evaluated by developing a surface runoff model to confirm flow mitigation and runoff retention within the watershed.

\section{Material and methods}

\subsection{Project area}

The site development involved construction of an aquatics center in an 11.4 acre parcel located in Tallahassee, Florida, USA. The latitude and longitude of the site shown in Google Earth is $30^{\circ} 25^{\prime} 02^{\prime \prime} \mathrm{N}$ and $84^{\circ} 18.54^{\prime} 57^{\prime \prime} \mathrm{W}$. Before development, the parcel was a wooded area; mainly consisted of pine, oak and cedar trees. The new development created 2.4 acre impervious area due to the construction of swimming and diving pool complex (pools were considered as impervious), buildings, parking lot and driveway access (Figure 1). This site (11.4 acre parcel) was entirely within a large parcel that encompasses a golf course that belonged to the same owner. The pond in the golf course (is addressed 'offsite pond' hereafter), shown in Figure 1, is considered to be in an isolated small closed basin. According to local closed basin rules, the offsite pond should retain all the runoff that it receives. 


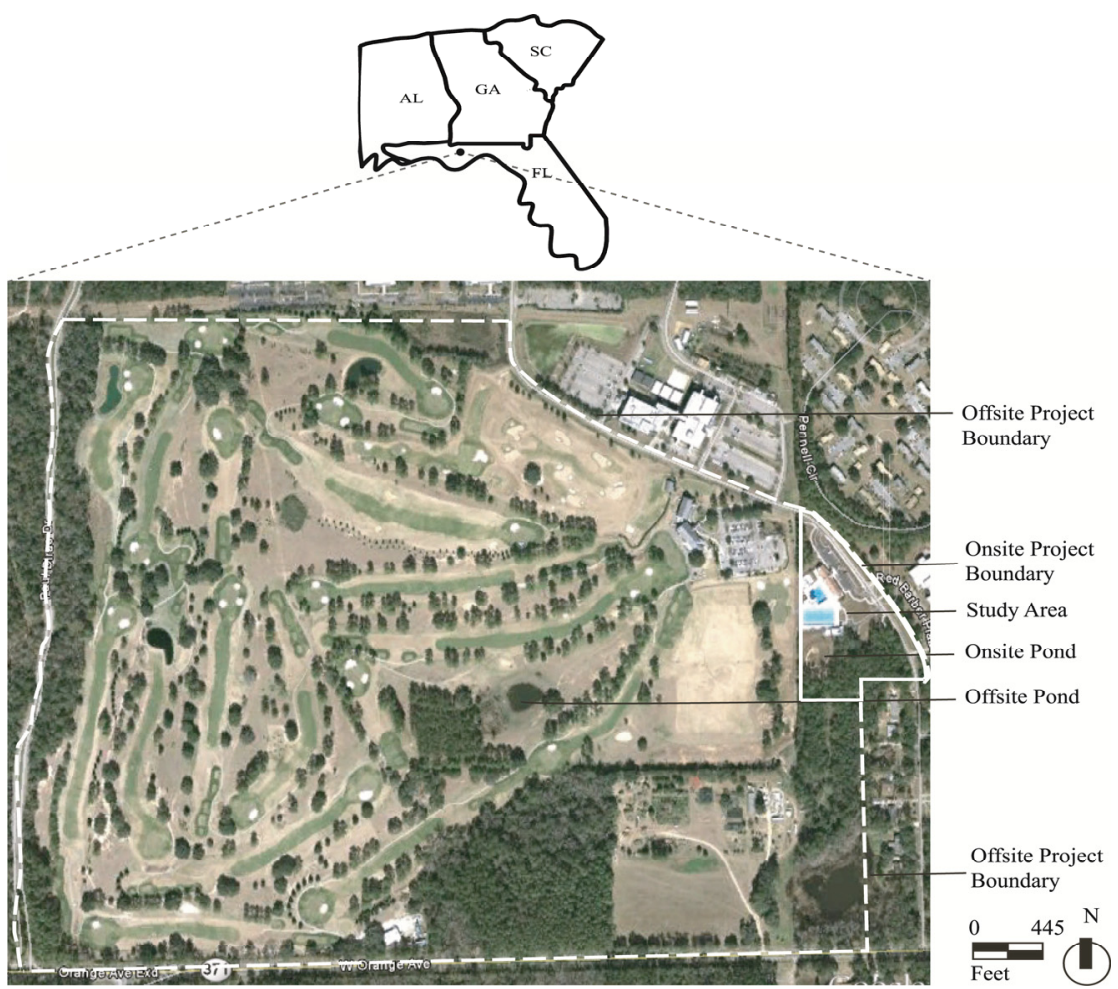

Figure 1: $\quad$ Site location (after construction) - courtesy Google Earth.

According to Soil Survey of Leon County Florida, USDA [7], the soil type in the site is Orangeburg Fine Sandy Loam (2-5\% grade). The hydrologic group of the soil is ' $\mathrm{B}$ '. The soil in this area consists of stratum of clayey sand in the upper stratums and with silty sand at a lower stratum. The soil investigation in the site suggested that the groundwater was between 23 to 27 feet below the surface and it may change 10 feet or more during wet season. The percolation rate in the south side was found very low (1.5 inch per day on average).

\subsection{Runoff model}

The Interconnected Channel and Pond Routing (ICPR v3.10) program [8] was used to develop the runoff model for the study area. ICPR, accepted by Federal Emergency Management Agency (FEMA) for use on flood plain investigation is a widely used program throughout Florida and United States [9]. The ICPR model simulates the runoff using SCS method for a design storm when the drainage area, curve numbers and time of concentrations of the basin are known.

The Florida Department of Transportation (FDOT) rainfall distribution information [10] was used to simulate the runoff. Simulations were run for $25 \mathrm{yr}$ (to meet the local design criteria) and $100 \mathrm{yr}$ (extreme flow condition) design storms to evaluate the design. Rainfall depths of 7.4 inch (25 yr $8 \mathrm{hr}), 8.7$ inch 
(25 yr $24 \mathrm{hr}$ ), 8.9 inch (100 yr $8 \mathrm{hr}$ ), 11.5 inch (100 yr $24 \mathrm{hr}$ ) determined from (FDOT) IDF curves were used to simulate the runoff.

\section{Hydrologic analysis and evaluation}

\subsection{Pre-development analysis}

The first step in the hydrologic evaluation process was to delineate pre- and postdevelopment basins contributing to the offsite flow. Figure 2 displays the predevelopment basins. During the determination of pre-development basins at the project site (11.4 acre wooded area), two individual sub-basins were delineated. It was found that the runoff from Pre Onsite Basin-1 was discharged through a 24-inch Corrugated Metal Pipe (CMP) towards the east side of the property and the runoff from Pre Onsite Basin-2 was towards south side. Besides these onsite basins, the Offsite Basin (within the golf course) was delineated for the area which drains into the offsite pond.

Table 1: $\quad$ Pre-development analysis - ICPR input parameters.

\begin{tabular}{|c|c|c|c|c|c|}
\hline Basin & $\begin{array}{c}\text { Impervious } \\
\text { Area (acre) }\end{array}$ & $\begin{array}{c}\text { Pervious Area } \\
(\text { acre) }\end{array}$ & $\begin{array}{c}\text { Total } \\
(\text { acres })\end{array}$ & $\begin{array}{c}\text { Curve } \\
\text { Number }\end{array}$ & $\begin{array}{c}\mathrm{t}_{\mathrm{c}} \\
(\mathrm{min})\end{array}$ \\
\hline $\begin{array}{c}\text { Pre Onsite } \\
\text { Basin-1 }\end{array}$ & - & 4.3 & 4.3 & 55.0 & 37.7 \\
\hline $\begin{array}{c}\text { Pre Onsite } \\
\text { Basin-2 }\end{array}$ & - & 7.1 & 7.1 & 55.0 & 27.6 \\
\hline Offsite Basin & - & 41.9 & 41.9 & 61 & 22.7 \\
\hline
\end{tabular}

Table 1 depicts the numeric values used to calculate the runoff volume and peak discharge from pre-development basins using the model developed by ICPR program. Table-2 presents the pre-development runoff results. For the design storm of 25-year (local design criteria), the calculated peak runoff from onsite basins were determined to be 5.2 cfs (from Pre Onsite-Basin-1) towards east and $9.3 \mathrm{cfs}$ (from Pre Onsite Basin-2) toward south (25-year, 8-hr). The maximum volume of runoff was 1.2 acre-ft (from Pre Onsite-Basin-1) towards east and 1.9 acre-ft (from Pre Onsite Basin-2) towards south (25-year, 24-hr). The runoff generated from the Offsite Basin was captured in the offsite pond and there was no outflow from the offsite pond.

Table 2: $\quad$ Pre-development analysis - ICPR output parameters.

\begin{tabular}{|c|c|c|c|c|c|c|c|c|}
\hline \multirow{3}{*}{ Basin } & \multicolumn{4}{|c|}{ 25-yr Storm } & \multicolumn{4}{|c|}{ 100-yr Storm } \\
\hline & 8-hr & 24-hr & 8-hr & 24-hr & 8-hr & 24-hr & 8 -hr & 24-hr \\
\hline & \multicolumn{2}{|c|}{ Runoff (cfs) } & \multicolumn{2}{|c|}{$\begin{array}{l}\text { Runoff Volume } \\
\text { (acre-ft) }\end{array}$} & \multicolumn{2}{|c|}{ Runoff (cfs) } & \multicolumn{2}{|c|}{$\begin{array}{l}\text { Runoff Volume } \\
\text { (acre-ft) }\end{array}$} \\
\hline $\begin{array}{c}\text { Pre Onsite } \\
\text { Basin - } 1\end{array}$ & 5.2 & 1.6 & 0.9 & 1.2 & 7.5 & 2.8 & 1.2 & 1.9 \\
\hline $\begin{array}{c}\text { Pre Onsite } \\
\text { Basin }-2 \\
\end{array}$ & 9.3 & 2.7 & 1.4 & 1.9 & 13.2 & 4.6 & 2.0 & 3.2 \\
\hline Offsite Basin & 70.4 & 20.3 & 10.4 & 13.9 & 96.2 & 32.0 & 14.4 & 21.9 \\
\hline
\end{tabular}




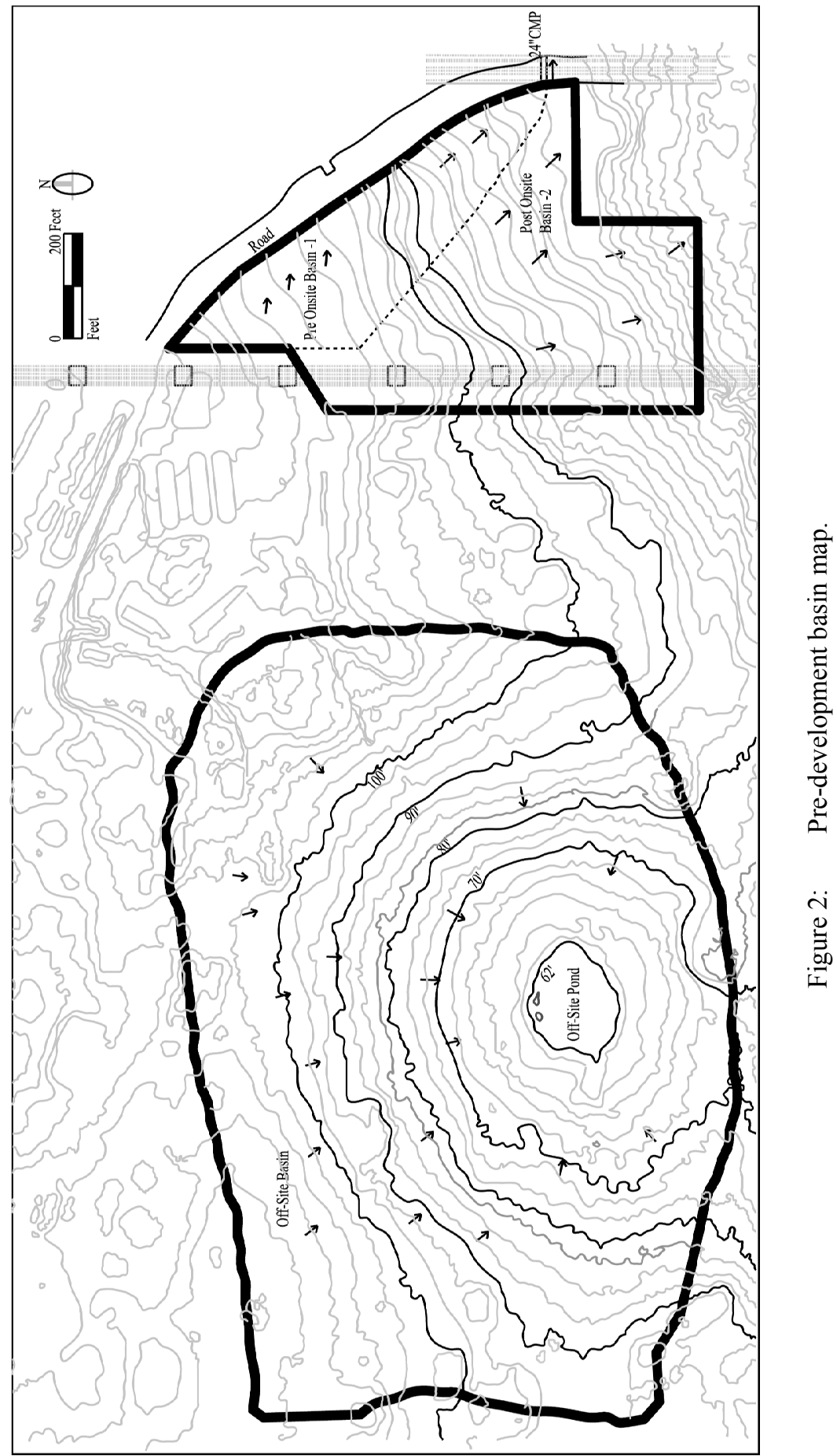




\subsection{Post-development analysis}

In the post-development condition (Figure 3), the topography and the land usage of the 11.4 acre onsite basin was significantly different from the predevelopment condition. The area of the post-development basins contributing runoff towards east (Post Onsite-Basin-1) and south (Post Onsite-Basin-2) was significantly reduced from pre-development condition. The land-cover of these two basins was changed from wooded area to grass cover (landscape). Besides these two basins, a new basin (Post Onsite Basin-Center) was also created approximately at the middle of the project area (Figure 3). The main change of topography and surface cover occurred in this basin. All the impervious area (2.4 acre) created due to construction of swimming and diving pool complex, buildings, parking lot, driveway access and offsite pond was within this central basin (Post Onsite Basin-Center).

For post-development basins, Table-3 depicts the numeric values used to calculate the peak flow and runoff volume using the ICPR model and Table 4 shows the model results. In the pre-development flow analysis, about 4.3 acre wooded area (Pre Onsite Basin-1) was contributing runoff towards east. However, based on the change in topography and surface cover (grass) of the portion of the site, the new, modified drainage basin (Post Onsite Basin-1) of approximately 2 acre decreased peak runoff from $5.2 \mathrm{cfs}$ to $3.4 \mathrm{cfs}$ towards east ( 25 year $8 \mathrm{hr}$ ). The volume of runoff towards east also decreased from $1.2 \mathrm{acre}-\mathrm{ft}$ to 0.7 acre-ft ( 25 year $24 \mathrm{hr}$ ). Additionally, in pre-development the estimated peak runoff from the 7 acre wooded area (Pre Onsite-Basin-2) towards south was $9.3 \mathrm{cfs}$, while in post-development condition, runoff from approximately 6.4 acre (Post Onsite-Basin-2) was reduced to $9.0 \mathrm{cfs}$ ( 25 year $8 \mathrm{hr}$ ). The volume of runoff towards south was also decreased from 1.4 acre- $\mathrm{ft}$ to 1.3 acre-ft (25 year $24 \mathrm{hr}$ ). Besides these two onsite basins, the 41.9 acre Offsite Basin remains same before and after the development of 11.4 acre parcel and there was no change in runoff contribution from this Offsite Basin. However, the peak runoff generated from Post Onsite Basin-Center, where major construction took place, was calculated to be $9.1 \mathrm{cfs}$ ( 25 year $8 \mathrm{hr}$ ) with a total volume of 1.9 acre-ft ( 25 year $24 \mathrm{hr}$ ). This flow and volume of runoff needed to be managed and retained within the property of the owner.

Table 3: $\quad$ Post-development analysis - input parameters.

\begin{tabular}{|c|c|c|c|c|c|}
\hline Basin & $\begin{array}{c}\text { Impervious } \\
\text { Area (acre) }\end{array}$ & $\begin{array}{c}\text { Pervious Area } \\
(\text { acre })\end{array}$ & $\begin{array}{c}\text { Total } \\
(\text { acres })\end{array}$ & $\begin{array}{c}\text { Curve } \\
\text { Number }\end{array}$ & $\mathrm{t}_{\mathrm{c}}(\mathrm{min})$ \\
\hline $\begin{array}{c}\text { Post Onsite } \\
\text { Basin-1 }\end{array}$ & - & 2.0 & 2.0 & 63.1 & 32.4 \\
\hline $\begin{array}{c}\text { Post Onsite } \\
\text { Basin-2 }\end{array}$ & - & 6.4 & 6.4 & 56.8 & 26.3 \\
\hline $\begin{array}{c}\text { Post Onsite } \\
\text { Basin-Center }\end{array}$ & 2.4 & 0.7 & 3.1 & 90.0 & 16.0 \\
\hline Offsite Basin & - & 41.9 & 41.9 & 61.0 & 22.7 \\
\hline
\end{tabular}


Table 4: $\quad$ Post-development analysis - output parameters.

\begin{tabular}{|c|c|c|c|c|c|c|c|c|}
\hline \multirow{3}{*}{ Basin } & \multicolumn{4}{|c|}{$25-\mathrm{yr}$} & \multicolumn{4}{|c|}{$100-y r$} \\
\hline & 8-hr & 24-hr & 8-hr & 24-hr & 8-hr & 24-hr & 8-hr & 24-hr \\
\hline & \multicolumn{2}{|c|}{ Runoff (cfs) } & \multicolumn{2}{|c|}{$\begin{array}{l}\text { Runoff Volume } \\
\text { (acre-ft) }\end{array}$} & \multicolumn{2}{|c|}{ Runoff (cfs) } & \multicolumn{2}{|c|}{$\begin{array}{l}\text { Runoff Volume } \\
\text { (acre-ft) }\end{array}$} \\
\hline $\begin{array}{c}\text { Post Onsite } \\
\text { Basin - } 1\end{array}$ & 3.4 & 1.2 & 0.5 & 0.7 & 4.7 & 1.6 & 0.7 & 1.1 \\
\hline $\begin{array}{c}\text { Post Onsite } \\
\text { Basin }-2\end{array}$ & 9.0 & 2.6 & 1.3 & 1.8 & 12.7 & 4.3 & 1.9 & 3.0 \\
\hline $\begin{array}{c}\text { Post Onsite } \\
\text { Basin - Center }\end{array}$ & 9.1 & 2.6 & 1.6 & 1.9 & 11.1 & 3.4 & 2.0 & 2.6 \\
\hline Offsite Basin & 70.4 & 20.3 & 10.4 & 13.9 & 96.2 & 32.0 & 14.4 & 21.9 \\
\hline
\end{tabular}

\subsubsection{Storm water management design}

To manage the excess runoff from the central basin (Post Onsite Basin-Center), the flow was allowed to route through a newly designed dry detention facility (onsite pond) at the 11.4 acre site. The new six feet deep onsite pond (Table-5) receives the runoff by overland flow and underground pipe networks (combination of inlets and pipes) from the central basin. This pond was designed to retain as much water as possible; safely releasing excess volume to downstream to the offsite pond at the golf course. To achieve this, the outflow structure of the onsite pond was optimized for maximum storage (with 3 feet free-board). The top opening of the outflow structure (FDOT Type-C inlet with 2 feet by 3 feet top) was 2.21 feet above the bottom of the pond (at elevation of 87.21 feet) allowing the pond to have 0.36 acre-ft treatment capacity, a requirement set by local regulatory agency. A side bank filter (infiltration rate 4.7 feet per hour) with top area 487 square feet was also provided in the onsite pond. An 18-inch 1345 feet long subsurface pipe (slope 1.6\%) was used to connect the outflow structure (of onsite pond) to the offsite pond (at golf course), which is the ultimate discharge point for the runoff from 2.4 acre central basin. This network allowed the two ponds to operate in series (Figure 3).

Table 5: $\quad$ Onsite pond water-level elevations vs. storage area.

\begin{tabular}{|c|c|c|}
\hline $\begin{array}{c}\text { Elevation } \\
\text { (ft) }\end{array}$ & $\begin{array}{c}\text { Area } \\
\text { (acre) }\end{array}$ & $\begin{array}{c}\text { Cumulative Volume } \\
\text { (acre-ft) }\end{array}$ \\
\hline 85 & 0.11 & 0.0 \\
\hline 86 & 0.13 & 0.1 \\
\hline 87 & 0.16 & 0.6 \\
\hline 88 & 0.19 & 0.4 \\
\hline 89 & 0.23 & 0.7 \\
\hline 90 & 0.26 & 0.9 \\
\hline 91 & 0.30 & 1.2 \\
\hline
\end{tabular}




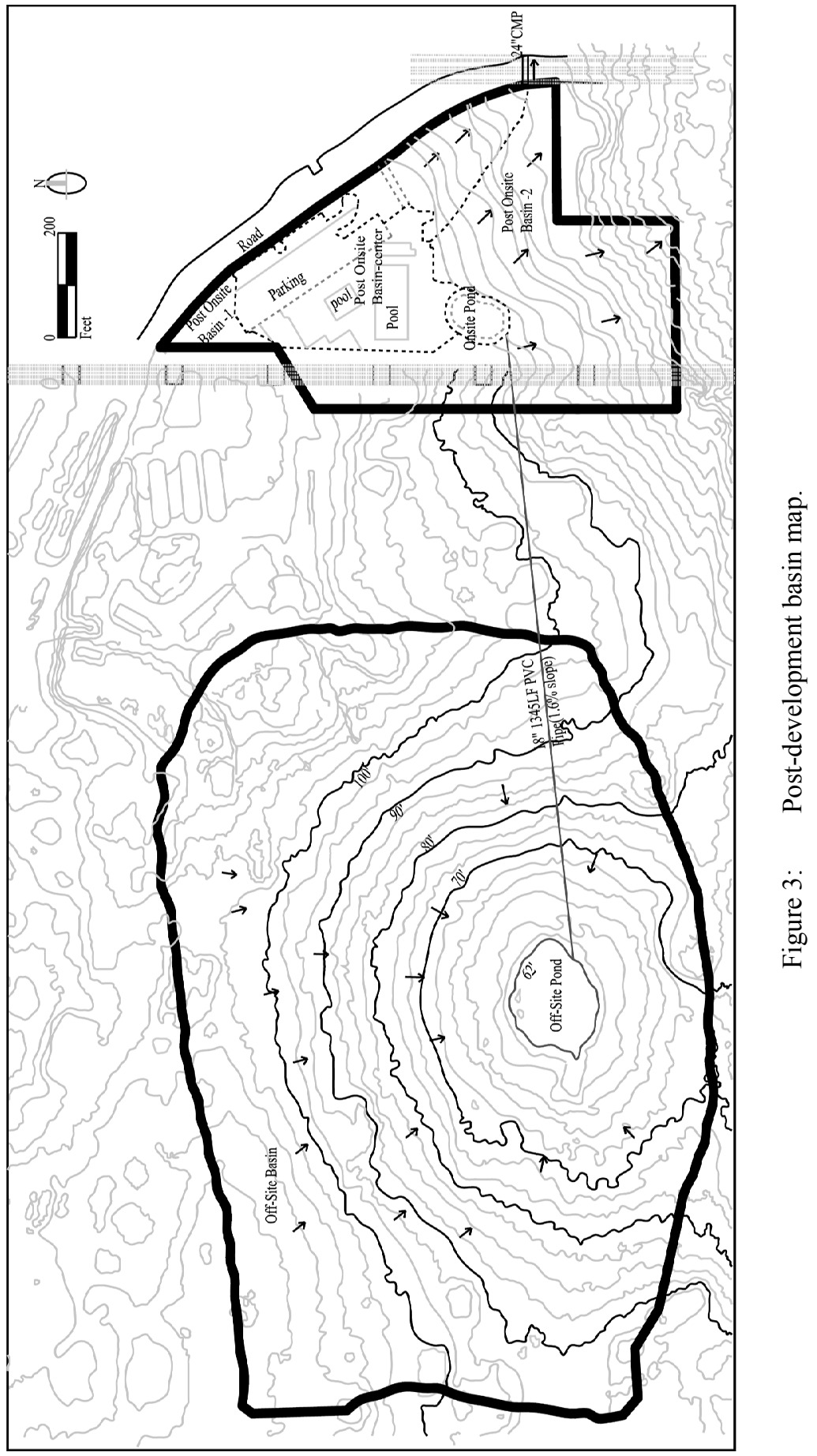


3.2.1.1 Onsite pond performance The water surface elevation for the onsite pond during the routing is displayed in Figure 4. Additionally, the inflow to the onsite pond and overflow through the discharge structure is plotted in Figure 5. The numeric values of Table 3, 5 and 6 were used to determine the water surface elevations and the hydrographs. It is seen that the onsite pond can route flows of 25 year storm and safely passes even the larger storms (100 year return period) maintaining safe freeboard (Figure 4).

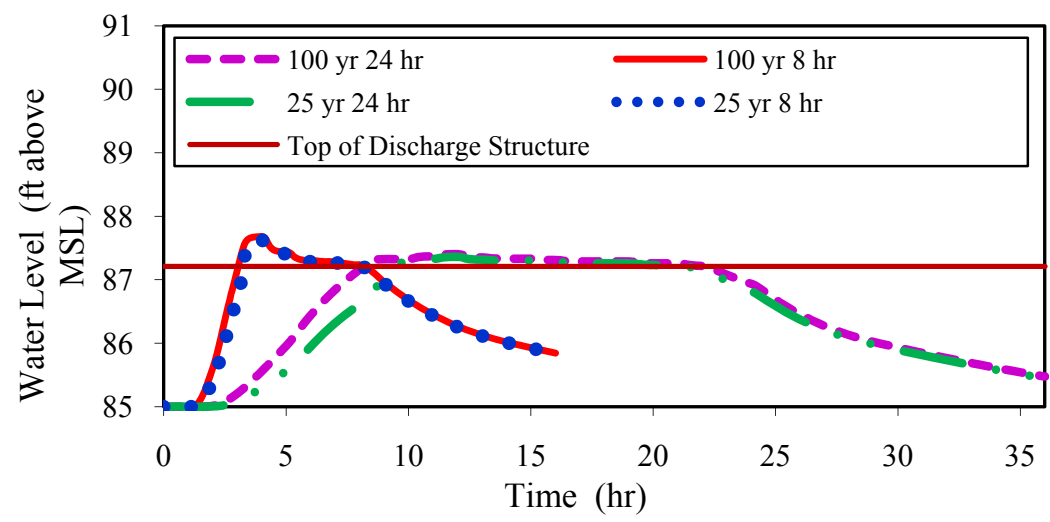

Figure 4: Water levels in the onsite pond.
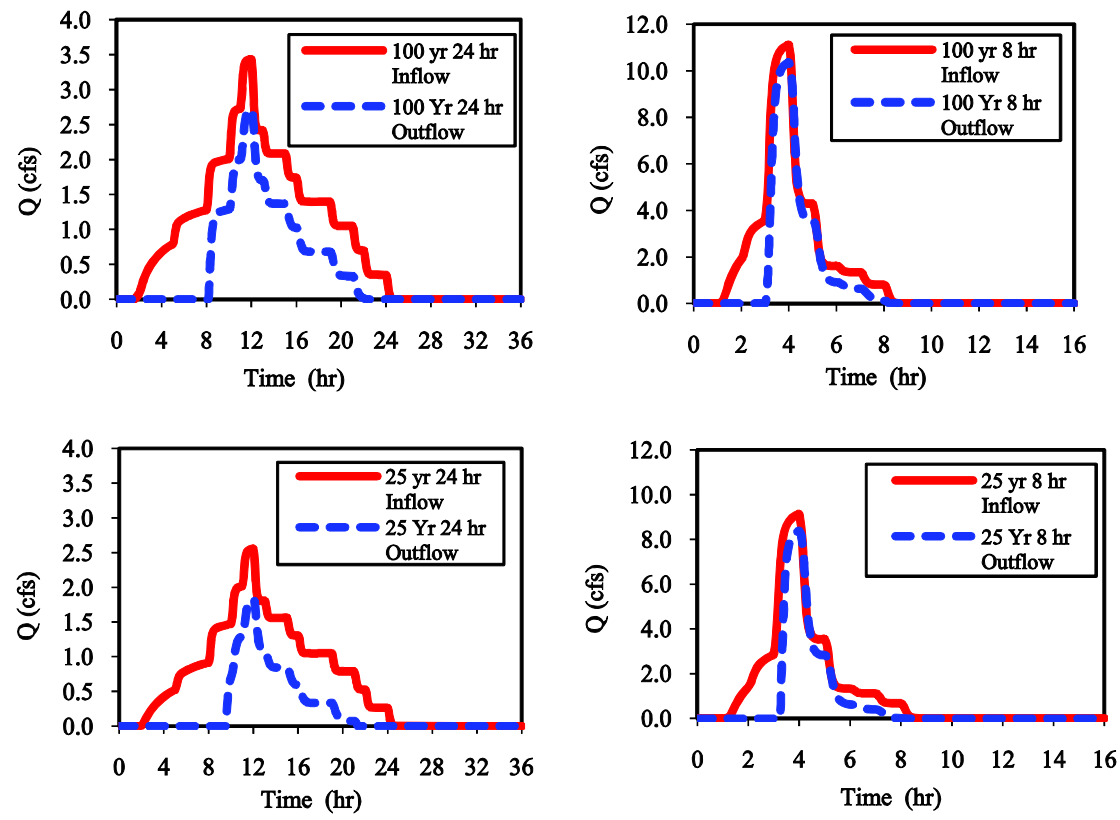

Figure 5: Inflow and outflow hydrographs - onsite pond. 
3.2.1.2 Offsite pond performance Recognizing the safety associated with retaining water in the offsite pond at golf course; simulation (using ICPR program) was performed to check if the offsite pond has enough capacity to retain both the routed discharge from onsite pond and the runoff from its own offsite basin.

The offsite pond was evaluated for same storm events ( $8 \mathrm{hr}$ and $24 \mathrm{hr}$ ) with return period 25 year and 100 year for the post condition. The numeric values of Table-3, 5 and 6 were used to run the model. The pond percolation rate was considered 1 inch per day, obtained from onsite test. Maximum water levels computed for $25 \mathrm{yr}$ and $100 \mathrm{yr}$ storm were $68.56 \mathrm{ft}$ (25 year $24 \mathrm{hr}$ ) and $70.4 \mathrm{ft}$ (100 year $24 \mathrm{hr}$ ) respectively (Figure 6). This pond essentially has the 'pop-off' at elevation 73 . This simulation showed that the offsite pond can also retain extreme storm events (e.g. 100 year $24 \mathrm{hr}$ storm).

Table 6: $\quad$ Offsite pond water level elevations vs. storage.

\begin{tabular}{|c|c|c|}
\hline Elevation (ft) & Area (Ac) & $\begin{array}{c}\text { Cumulative Volume } \\
\text { (acre-ft) }\end{array}$ \\
\hline 60 & 0.5 & 0.0 \\
\hline 62 & 0.8 & 1.4 \\
\hline 64 & 1.1 & 3.3 \\
\hline 66 & 2.0 & 6.5 \\
\hline 68 & 3.3 & 11.8 \\
\hline 70 & 4.6 & 19.6 \\
\hline 72 & 6.3 & 30.5 \\
\hline
\end{tabular}

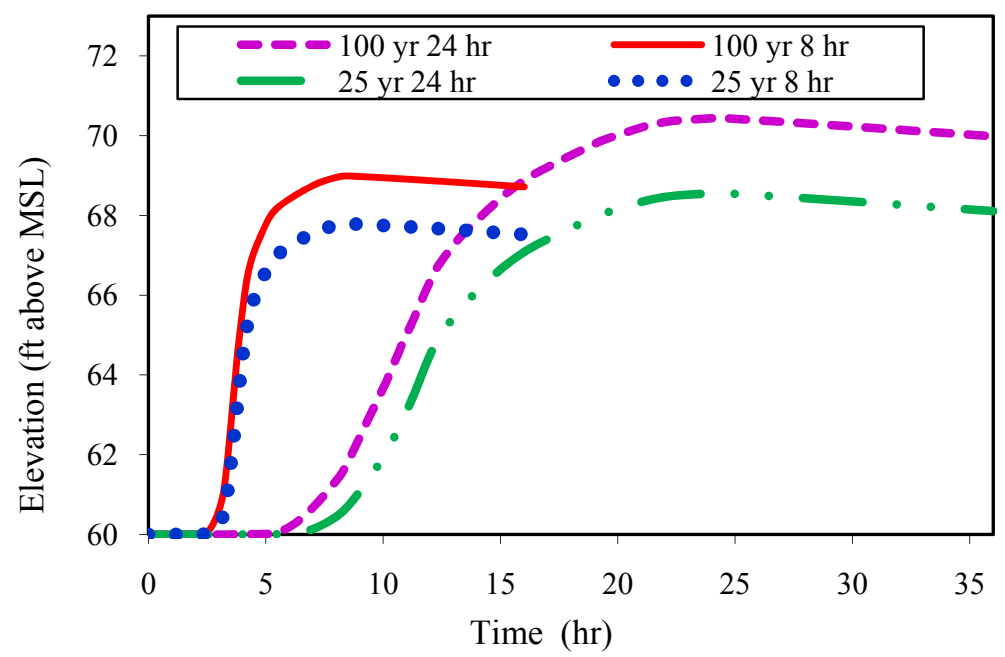

Figure 6: Water levels in the offsite pond. 


\section{Conclusion}

This article presented an analysis of a storm water management design to contain runoff within the watershed using two ponds in series for a land development project. The analysis evaluated the storm water management strategy by calculating flow rate and volumetric flow for storms with return periods of twenty-five and one hundred years. The study showed that the post-development runoff towards east and south side of project area was significantly reduced from the pre-development level. The results confirmed that the runoff generated due to the impervious area construction in the site could be safely retained by using the two ponds in series without over-topping the banks.

\section{References}

[1] Burns D., Vitvar, T., McDonnell, J., Hassett, J., Duncan, J. \& Kendall, C., Effects of suburban development on runoff generation in the Croton River basin, New York, USA. Journal of Hydrology, 311, pp. 266-281, 2005.

[2] Selvalingam, S., Liong, S.Y. \& Manoharan, P.C., Use of RORB and SWMM models to an urban catchment in Singapore. Advances in Water Resources, 10, pp. 78-86, 1987.

[3] Wheatera, H. \& Evans, E., Land use, Water management and future flood risk. Land Use Policy, 26, S251-S264, 2009.

[4] Tsihrintzis, V. A. \& Hamid, R., Urban stormwater quantity/quality modeling using the SCS method and empirical equations. Journal of the American Water Resource Association, 33(1), 163-176, 1997.

[5] Chen, J. \& Adams, B. J., Development of analytical models for estimation of urban stormwater runoff, Journal of Hydrology, 336, 458-469, 2007.

[6] Schaad D. E., Farley, J. \& Haynes, C., Design and routing of storm flows in an urbanized watershed without surface streams. Journal of Hydrology, 375, 334-344, 2009.

[7] Soil Survey of Leon County Florida, USDA, Issued February 1981, Online. http://soildatamart.nrcs.usda.gov/manuscripts/FL073/0/Leon.pdf

[8] Interconnected Channel and Pond Routing Model (ICPR), version 3.10 (2002) Streamline Technologies, Inc., Winter Springs, Florida, U.S.A.

[9] Singhofen, P. J., Calibration and verification of stormwater models, Florida Association of Stormwater Utilities 2001 Annual Conference, June 20-22, 2001 Online. http://www.streamnologies.com/support/pdfs/Calibration.pdf

[10] State of Florida Department of Transportation (FDOT) (2010) Drainage Manual, Tallahassee Florida. Online.http:/www.dot.state.fl.us/rddesign /dr/files/2010DrainageManual.pdf http://www.dot.state.fl.us/rddesign/dr /files /IDFCurves.pdf 